\title{
Grazing intensities, vegetation, and heifer gains: 55 years on shortgrass
}

\author{
RICHARD H. HART AND MARY M. ASHBY
}

Authors are rangeland scientist and rangeland technician, USDA, Agricultural Research Service, High Plains Grasslands Research Station, Cheyenne, Wyo., and Central Plains Experimental Range, Nunn, Colo., respectively.

\begin{abstract}
Shortgrass rangeland, dominated by blue grama (Bouteloua gracilis [H.B.K.] Lag. ex Steud), was grazed at 3 intensities, equivalent to mean stocking rates of $16.7,23.0$, and 36.5 heiferdays ha-1, from 1939 through 1994 . Few changes in plant communities had been documented by the early 1970's. In 1992-1994, frequency of occurrence, basal and foliar cover, and biomass at peak standing crop (PSC) were determined on the remaining pasture at each grazing intensity, and on 3 ungrazed exclosures. Blue grama and buffalograss (Buchlö̈ dactyloides [Nutt.] Engelm.) increased, and western wheatgrass (Pascopyrum smithii [Rydb.] A. Love) and needle-and-thread (Stipa comata Trin. \& Rupr.) decreased, as grazing intensity increased. Redtbree-awn (Aristida longiseta Steud.) was most plentiful under light grazing. Basal cover and biomass of forbs were lower under grazing than in exclosures, but differences in biomass were not significant. Shrubs and half-shrubs decreased as grazing intensity increased. Frequency and cover of plains pricklypear (Opuntia polyacantha Haw.) were higher in the exclosures and under light grazing than under moderate or heavy grazing; biomass was 4 to 6 times as high in the exclosures as under any grazing intensity. Heifer gains declined linearly with increasing grazing pressure index. Optimum (most profitable) stocking rate was about $20 \%$ higher than that under the moderate grazing intensity, under which biomass production was maintained and shrub and pricklypear remained at low levels. Returns to land, labor, and management were only slightly higher under the optimum stocking rate than under the moderate grazing intensity. The moderate grazing intensity appears to be both profitable and sustainable.
\end{abstract}

Key Words: basal cover, frequency, foliar cover, herbage yields, plains pricklypear, plant community composition

\section{Introduction and Historical Perspective}

The shortgrass steppe evolved under intensive year-round grazing by large ruminant herbivores. Larson (1940) concluded that the shortgrass plains are a true climax, not a grazing disclimax, because bison and other wild herbivores were an integral part of the ecosystem as it developed

The authors thank rangeland scientists $W$. R. Houston, R. E. Bement, D. N Hyder, Marvin C. Shoop, W. A. Laycock, and J. R. Forwood; rangeland technicians R. E. Engle, R. R. Kerbs, and J. B. Thomas; and all the other scientists and technicians who kept this study going in the $1960^{\prime} \mathrm{s}, 1970$ 's, and $1980^{\circ} \mathrm{s}$.

Manuscript accepted 2 Nov 1997.
Wild herbivores stocked the shortgrass steppe to maximum carrying capacity. Their numbers were controlled only by interactions of forage availability, extremes of weather, predators, and Native American hunters (Larson 1940, Hart and Norton 1988, Hart and Hart 1997). Growth and reproductive rates were just sufficient, over the long term, to maintain a dynamic equilibrium between animal populations and controlling factors.

With the removal of bison and elk and the reduction in pronghorn antelope, cattle became the primary consumers of forage on shortgrass. Most cattle producers strive for growth and reproductive rates of their stock which maximize the profits from animals and animal products. It is essential, for profitability and sustainability of livestock enterprises, to determine the effects of stocking rate on rangeiand vegetation and livestock performance.

Selective grazing by livestock is usually held responsible for driving shifts in plant community composition. At the Central Plains Experimental Range (CPER) near Nunn, Colo., Vavra et al. (1977) found that cattle grazed $97 \%$ and $88 \%$ of the available western wheatgrass (Pascopyrum smithii [Rydb.] A. Love) under heavy and light grazing, respectively, but only $32 \%$ and $16 \%$ of the available blue grama (Bouteloua gracilis [H.B.K.] Lag. ex Steud).

Milchunas et al. (1989) examined interactions of grazing, topographic position, and current year precipitation after 47 years of grazing at CPER. They concluded that short-term weather had the greatest influence in shaping plant community structure, and topographic position had the least, while grazing effects were intermediate. Hyder et al. (1975) found that needle-and-thread (Stipa comata Trin. \& Rupr.) generally decreased and pricklypear (Opuntia polyacantha Haw.) and blue grama increased under heavy summer grazing at CPER. However, they stated "...most of the significant effects of repeated heavy grazing were derived from isolated events-interactions between weather and grazing."

Launchbaugh $(1957,1967)$ agreed that weather could mask effects of stocking rate. In a very dry year in western Kansas, western wheatgrass disappeared from lightly- and moderatelygrazed mixed prairie, temporarily converting it to typical shortgrass steppe. When precipitation returned to normal, western wheatgrass returned to the same abundance recorded before the grazing experiment began. On the other hand, western wheatgrass nearly disappeared from the heavily-grazed pastures after 10 years of grazing and never returned. Heavy, moderate and light stocking rates were $0.8,1.4$ and 2.0 ha steer $^{-1}$ on this study.

After 7 years of heavy vs. moderate stocking at the Southeastern Colorado Research Center near Springfield, Colo., "...the heavily-grazed pasture showed obvious symptoms of low 
plant vigor...(and) more bare soil, along with dead and partially dead perennial forage plants" (Cook and Rittenhouse 1988).

Undesirable plants ("weeds") have been thought to increase under heavy grazing, but bottlebrush squirreltail, red three-awn (Aristida longiseta Steud.), fringed sagewort (Artemsia frigida Willd.), and combleaf evening primrose (Oenothera coronopifolia Torr. \& Gray), all opportunistic-colonizer species, increased under zero grazing at CPER (Milchunas et al. 1989). Milchunas et al. (1992) seeded kochia (Kochia scoparia [L.] Schrad.), Russian thistle (Salsola iberica Senn. \& Pau), Jim Hill mustard (Sisymbrium altissimum L.), plains pepperweed (Lepidium densiflorum Schrad.) and Canada thistle (Cirsium arvense [L.] Scop.) into heavily grazed and ungrazed rangeland at CPER. None survived on the grazed plots, but enough kochia and Russian thistle survived on the ungrazed plots to significantly increase the density of these species 1 year later. Both studies indicate that protection from grazing, rather than grazing, increased susceptibility of rangeland to invasion by several weedy species. Milchunas et al. (1990) stated "...the lack of grazing promoted species characteristic of disturbances," perhaps because disturbances by rodents were more frequent in the ungrazed exclosures.

At the Central Plains Experimental Range, a grazing intensity study was begun on typical shortgrass rangeland in 1939 and continues, in truncated form, to the present. This study presented a unique opportunity to examine the long-term effects of protection from grazing and grazing at different intensities on plant community composition and cattle gains.

\section{Site and Study Methods}

The Central Plains Experimental Range (CPER) is about $20 \mathrm{~km}$ northeast of Nunn, Colo.and $50 \mathrm{~km}$ south of Cheyenne, Wyo; CPER headquarters is at about $104^{\circ} 40^{\prime} \mathrm{W} 40^{\circ} 40^{\prime} \mathrm{N}$. Total annual precipitation ranged from 130 to $500 \mathrm{~mm}$ over the course of this grazing study, with 50 to $80 \%$ falling in May through September. Major soil types on the study pastures were Ascalon fine sandy loan (fine-loamy mixed mesic Aridic Argiustoll), Renohill fine sandy loam (fine montmorillonitic mesic Ustollic Haplargid), Shingle clay loam (loamy, mixed [calcareous], mesic, shallow Ustic Torriorthent), and Nunn loam and clay loam (fine, montmorillonitic, mesic Aridic Argiustolls).

Vegetation was dominated by the warm-season shortgrasses blue grama and buffalograss (Buchlö̈ dactyloides [Nutt.] Engelm.), and red threeawn. The cool-season midgrasses western wheatgrass and needle-and-thread made up a small but significant component of the vegetation. Plains pricklypear, fringed sagewort, scarlet globemallow, slimflower scurfpea (Psoralea tenuiflora Pursh), slenderbush eriogonum (Erogonum microthecum Nutt.), and scarlet gaura were abundant.

In 1939, grazing began on 4 replications of a grazing intensity study at the CPER, but no data were taken until 1940. Between 1950 and 1978, replicates were removed from the system until only a single pasture, of approximately $128 \mathrm{ha}$, remained at each intensity. Pastures were grazed each year by yearling Hereford heifers. From 1940 through 1964, light, moderate, and heavy grazing pastures were stocked and grazed to remove 20,40 , and $60 \%$, respectively, of the current year's growth of grasses during a 6-month grazing season, May through October. From 1965 through 1994, light, moderate, and heavy grazing were stocked to leave a total of 500,335 , and $225 \mathrm{~kg} \mathrm{ha}^{-1}$ of ungrazed herbage at the end of the grazing season. This represented an increase in grazing intensities; removing 20,40 , and $60 \%$ of the average annual herbage production of $700 \mathrm{~kg} \mathrm{ha}^{-1}$ would have left 560 , 420 , and $280 \mathrm{~kg} \mathrm{ha}^{-1}$, with more left in a year of above-average herbage production.

Grazing began in May of each year and continued for a maximum of 184 days under all 3 grazing intensities. In years of limited forage production, the season was as short as 47 days under light, 89 days under moderate, and 48 days under heavy stocking. Animal numbers per pasture ranged from 6 to 22 under light, 11 to 29 under moderate, and 14 to 45 under heavy stocking over the years 1939 through 1994. Cattle were weighed at the beginning and end of the grazing season; initial weights were 200 to $300 \mathrm{~kg}$. Information on initial condition, breed, and how cattle were assigned to treatments was not recorded.

In 1992 through 1994, detailed measurements of plant species frequency, cover, and peak standing crop (PSC) of above-ground biomass were made on the remaining replication of the grazing intensity study at CPER. Sixty permanent, systematically spaced, $1.5 \times 1.5 \mathrm{~m}$ plots were located in each pasture. Biomass estimates from cages on or near these plots were used to calculate grazing pressure index. Cages were moved a few meters each spring before plant growth started. In addition, 20 permanent 1.5 $\times 1.5 \mathrm{~m}$ plots per pasture were located in a 0.4 to 0.8 ha exclosure and 20 more were located outside and adjacent to the exclosure. Data from these plots were used to estimate effects of grazing intensity, including zero grazing, on plant species frequency, cover, and biomass.

Biomass production was estimated on the plots distributed over the pastures by the micro-unit forage inventory method (Shoop and McIlvain 1963), a double-sampling technique using clipping and ocular estimation. Biomass production was estimated in two $30 \times 60 \mathrm{~cm}$ quadrats per plot; every fifth plot was clipped and weighed by species. Regression analysis of species weights on visual estimates in the clipped quadrats was used to adjust visual estimates of production if necessary. In nearly all cases, regression slopes not significantly different from 1.00 and intercepts not significantly different from zero indicated adjustment was not needed. Standing biomass of pricklypear was estimated by harvesting, drying, and weighing 100 pads of pricklypear and calculating the average dry weight. Pads were counted in each quadrat, and the average dry weight was multiplied by the number of pads.

Frequency of occurrence was sampled on 200 quadrats in each plot area (Hyder et al. 1965). Blue grama frequency was estimated within a $5 \times 5$-cm quadrat, nested in the $40 \times 40$-cm quadrat used to estimate frequency of other species.

Basal and foliar cover (1993 and 1994 only) were estimated with a 10-point frame, placed at 5 locations near each of the plots inside and immediately outside the exclosures (Mueller-Dombois and Ellenberg 1974). This method is not directly comparable to the square-foot density method, which estimates a compromise between basal and aerial cover, but both provide estimates of the relative cover of each species among stocking treatments.

Because of the variety of methods used to estimate plant community composition, it was not possible to compare past results with those we obtained. However, past results were used to indicate that the initial composition of all 3 grazing intensities and the exclosures were essentially identical. 
Table 1. Aboveground standing crop biomass and litter, $15 \mathrm{July} 1970^{1}$, and root biomass, $2 \mathrm{July} 1970^{1}$, in ungrazed exclosures and in pastures grazed at 3 intensities, 1939-1970 (adapted from Sims et al. 1971).

\begin{tabular}{lcccc}
\hline Component & \multicolumn{2}{c}{ Grazing intensity } & Ungrazed \\
exclosure
\end{tabular}

Approximate dates on which maximum standing crop was reached; biomass changed very little thereafter.

I 0.05 Confidence nterval

${ }^{3}$ Confidence intervals not reported.

Statistical analysis was a problem because only a single replication of each grazing intensity remained, but zero grazing was represented by 3 exclosures which were considered as replications. All plant data were subjected to analysis of variance for partially replicated designs, using a program developed previously (R. H. Hart, unpublished). Differences among years were significant $(P$ $\leq 0.05$ ) in only 2 cases (shrub biomass and blue grama basal cover) and the years $X$ intensities interaction was never significant. Therefore, we calculated significant differences $(P \leq 0.05)$ between 2- or 3-year means of grazing intensities by the method of Goulden (1952) for unpaired observations with unequal sample numbers (ungrazed vs. any grazing intensity) or equal sample numbers (among grazing intensities).

\section{Results}

\section{Forage Production and Species Composition}

Klipple and Costello (1960) reported that blue grama increased from $59 \%$ of herbage production in $1940-42$ to $67 \%$ in $1952-53$; increase was similar among 3 stocking levels and between grazed and ungrazed rangeland. Needle-and-thread averaged $0.23 \%$ of production in 1940-42, but in 1952-53 contributed $0.13 \%$ on heavy, $0.33 \%$ on moderate, $0.70 \%$ on light, and $1.61 \%$ on zero grazing. Western wheatgrass decreased from 1940-41 to $1952-53$ on all treatments; from 1.11 to $0.12 \%$ on heavy, 0.71 to $0.22 \%$ on moderate, 1.97 to $0.82 \%$ on light, and 1.64 to $0.75 \%$ on zero grazing. Forb production decreased from $12.1 \%$ to $3.1 \%$ of total production, with no differences among treatments. The fraction of total production contributed by plains pricklypear showed little difference between periods or among treatments, with means of $6.4 \%$ in $1940-42$ and $5.7 \%$ in 1952-53. One cool-season grass, needle-and-thread, increased from 1940-42 to 1952-53, while another, western wheatgrass, decreased. With the exception of these very minor constituents, few changes in vegetative composition that could be attributed definitely to differences in stocking rate were detected during the first 14 years of grazing.

In 1970, Sims et al. (1971) found that total biomass of grasses decreased with increasing grazing intensity (Table 1). Biomass of forbs and shrubs and total biomuss of grasses, forbs, and shrubs were highest under light grazing. Litter was reduced under moderate grazing, but root biomass was higher than on any other treatment.
Also in 1970, Mitchell (1971) found that the frequency of blue grama was higher and that of needleleaf sedge (Carex eleocharis Bailey) was lower on all the grazed treatments than in a 30 -year exclosure (Table 2). The quadrat size used to determine frequency was not clearly defined. Frequency of scarlet globe"mallow and plains pricklypear was higher in the exclosure and under light grazing than under moderate or heavy grazing. Mitchell noted that pricklypear was highly clumped under heavy grazing and hypothesized that grazing increased temperature and dryness of surface soil, making it difficult for seedling cactus to establish and survive between established clumps. Under lighter grazing, pricklypear plants were numerous, producing a high frequency of occurrence, but tended to be smaller than in the heavy-grazed pasture, resulting in a lower biomass.

In 1971, Moir and Trlica (1976) sampled canopy cover in each grazing intensity and in the exclosures in the lightly and heavily grazed pastures. They defined 7 plant communities that appeared frequently in the areas sampled, and 4 plant communities that appeared only once or twice. Plant communities in the 2 exclosures were quite different (Table 3 ), but which exclosure was located in which pasture was not specified. Moir and Trlica (1976) concluded "The influence of livestock grazing upon vegetation composition is very slight" after 33 years of grazing. Two exceptions were noted. Cover of sedges was much higher in exclosure 1 than in exclosure 2 or in the grazed pastures. Under heavy grazing, cover of buffalograss was much higher on 1 plot than on the other 3 plots in that treatment or on any other treatment.

In 1992-1994, frequency of occurrence (Table 4) of blue grama and buffalograss increased with increasing intensity of grazing,

Table 2. Frequency of occurrence of selected plant species in 1970 . In ungrazed exclosures and in pastures grazed at 3 intensities, 1939-1970 (adapted from Mitchell 1971).

\begin{tabular}{|c|c|c|c|c|}
\hline \multirow[b]{2}{*}{ Component } & \multicolumn{3}{|c|}{ Grazing intensity } & \multirow{2}{*}{$\begin{array}{l}\text { Ungrazed } \\
\text { exclosure }\end{array}$} \\
\hline & Light & Moderate & Heavy & \\
\hline & $\ldots$ & $\ldots(\%)$ & $\ldots$. & $\ldots \ldots$ \\
\hline Blue grama & 93.1 & 94.3 & 98.1 & 86.1 \\
\hline Needleleaf sedge & 29.4 & 29.1 & 25.7 & 11.2 \\
\hline Red three-awn & 4.0 & 6.8 & 1.4 & 7.2 \\
\hline Scarlet globemallow & 16.5 & 4.0 & 7.2 & 18.1 \\
\hline Plains pricklypear & 11.6 & 5.0 & 6.2 & 18.0 \\
\hline
\end{tabular}


Table 3. Canopy cover ${ }^{1}$, in 1971 of selected plant species in ungrazed exclosures and in rangeland pastures grazed at 3 intensities, 1939-1971 (adapted from Moir and Trlica 1976).

\begin{tabular}{|c|c|c|c|c|c|}
\hline \multirow[b]{2}{*}{ Component } & \multicolumn{3}{|c|}{ Grazing intensity } & \multicolumn{2}{|c|}{ Ungrazed } \\
\hline & Light & Moderate & $\overline{\text { Heavy }}$ & Exclosure 1 & Exclosure 2 \\
\hline Blue grama & 54.4 & 66.6 & $\begin{array}{c}-(\%) \\
58.4\end{array}$ & 56.0 & 72.4 \\
\hline Buffalograss & 1.0 & 1.7 & 7.7 & 0.0 & 1.8 \\
\hline Sedges & 9.1 & 18.7 & 19.8 & 73.0 & 17.8 \\
\hline Red three-awn & 7.3 & 4.7 & 1.8 & 8.0 & 0.4 \\
\hline Needleandthread & 0.0 & 0.0 & 0.7 & 110 & 0.0 \\
\hline Western wheatgrass & 0.7 & 0.7 & 1.0 & 0.0 & 0.6 \\
\hline Fringed sagewort & 5.7 & 2.6 & 2.0 & 2.0 & 2.4 \\
\hline Plains pricklypear & 3.9 & 2.2 & 1.7 & 2.0 & 2.2 \\
\hline
\end{tabular}

Cover estimates are weighted averages of 5 transects (exclosures), 10 transects (lightly and moderately grazed pastures), and 16 transects (heavily grazed plasture). Data were not published for 4 transects on communities of minor importance in the heavily grazed pasture.

while frequency of western wheatgrass and needle-and-thread decreased. Red three-awn was much more frequent under light grazing than under any other treatment. Scarlet globemallow was less frequent under grazing than in the exclosures, with no differences among grazing intensities. The half-shrubs slenderbush-eriogonum, broom snake-weed and fringed sagewort occurred more frequently under light grazing than in the exclosures, but occurred infrequently under moderate or heavy grazing.

Foliar and basal cover of the 5 grasses (Table 4) followed trends similar to the trends in frequency. Cover of individual forb or shrub species was very small so the cover data for each of the 2 groups were pooled for analysis, as was not possible for frequency data. Foliar cover of forbs showed no definite trend, but basal cover was much lower under grazing than in the exclosures. Shrub cover showed the same pattern as frequency; high in the exclosures and under light grazing, low under moderate or heavy grazing. The same was true of pricklypear. Although cover of individual components of the plant community changed with grazing intensity, total plant foliar cover did not. However, total plant basal cover increased with increasing grazing intensity. Litter cover decreased with increasing intensity of grazing, and the proportion of bare ground increased, although the latter did not differ among light, moderate, and heavy grazing.

Biomass of warm- and cool-season graminoids (Table 4) did not differ among grazing intensities, but biomass of cool-season graminoids, including sedges, was much lower under grazing than in the exclosures. Biomass of warm-season graminoids was higher under moderate grazing than under any other treatment. Biomass of forbs did not differ among the 4 treatments. Total biomass of graminoids and forbs was higher in the exclosures and under moderate grazing than under light or heavy grazing. Shrub biomass (consisting mostly of the half-shrubs fringed sagewort, slenderbush eriogonum, and broom snakeweed) decreased markedly with increasing grazing intensity, reaching a maximum in the exclosures and diminishing to nearly nothing under heavy grazing. Plains pricklypear biomass also reached a maximum in the exclosures, nearly 4 to 6 times the biomass under grazing, but no differences were found among grazing intensities outside the exclosures. We found, as Mitchell (1971) did, a high frequency but not a high biomass of pricklypear under light grazing. Under moderate or heavy grazing, pricklypear was strongly clumped, producing the same biomass but a lower frequency than under light grazing. In the exclosures, both numbers and biomass of pricklypear were larger than under moderate or heavy grazing.
Conditions for seedling establishment and survival of pricklypear may have been improved by the absence of trampling and greater litter cover in the exclosures. Soil disturbance by rodents appeared to be more frequent in the exclosures and this may have favored establishment of pricklypear.

Plant community composition appeared to represent a continuum from no grazing to heavy grazing. We saw no indications of transitions to new steady states.

\section{Heifer Gains}

In the early years of this study, Klipple and Costello (1960) reported seasonal heifer gains in 1940-1949 of 129.2, 122.6, and $99.5 \mathrm{~kg} \mathrm{head}^{-1}$ under light, moderate, and heavy stocking, respectively, and 13.0, 18.9, and $25.7 \mathrm{~kg} \mathrm{ha}^{-1}$. Bement $(1969,1974)$ used the data of Klipple and Costello (1960) plus additional data from CPER to develop a stocking rate guide. This guide, similar to the model of Hart (1978), predicts a constant gain of $0.66 \mathrm{~kg} \mathrm{head}^{-1}$ day $^{-1}$ at stocking rates of less than 0.76 heifer mo ha ${ }^{-1}$ and gain head $^{-1} \operatorname{day}^{-1}(\mathrm{~kg})=0.993-0.437\left(\right.$ heifer mo ha $\left.{ }^{-1}\right)$ at higher stocking rates. Bement (1974) predicted maximum return ha ${ }^{-1}$ when $336 \mathrm{~kg} \mathrm{ha}^{-1}$ of ungrazed herbage remained on shortgrass rangeland at the end of a 6-month grazing season.

However, the amount of residue at maximum return will differ from Bement"s figure if total forage production and cattle prices differ from the values used in his calculations. For example, gains on rangeland producing $1,000 \mathrm{~kg} \mathrm{ha}^{-1}$ of forage will certainly be different from gains on rangeland producing $600 \mathrm{~kg} \mathrm{ha}^{-1}$ of forage, even though $336 \mathrm{~kg} \mathrm{ha}^{-1}$ of residue is left on both. On the other hand, the regression of average daily gain (ADG) on grazing pressure index (GPI) can be used to calculate the GPI at which maximum return is achieved for any combination of forage production and cattle prices (Hart 1978). Grazing pressure index is defined as heifer-days $\mathrm{Mg}^{-1}(1,000 \mathrm{~kg})$ of forage production at peak standing crop. Hart (1972) originally used the term "grazing pressure" to describe this ratio of animal-days to forage production, and grazing pressure was subsequently used in this way by McCartor and Rouquette (1977), Hart et al. (1976, 1983, 1988 a, 1988 b), Guerrero et al. (1984), and others. However, Scarnecchia (1985) re-defined grazing pressure as "animal demand per unit weight of forage at any instant" and defined grazing pressure index as "ratio of animal demand to forage over a period of time."

In the 44 years in which utilization was estimated, the target level of use was achieved in 86,63 , and $73 \%$ of the years under 
Table 4. Frequency of occurrence, foliar cover, basal cover, and biomass of plant species and species groups in ungrazed exclosures and in pastures grazed at 3 intensities, 1939-1994, on shortgrass steppe rangeland.

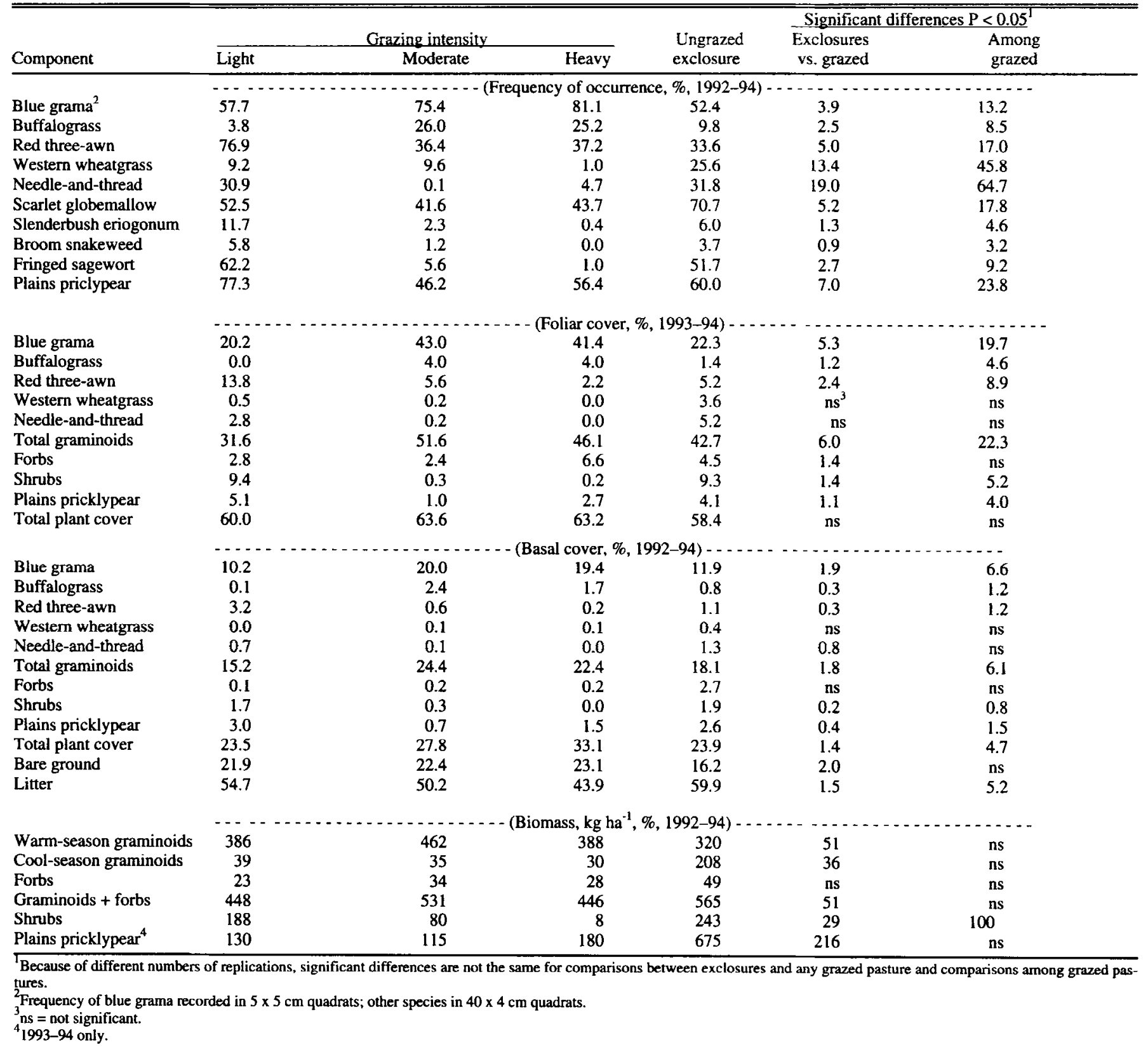

heavy, moderate, and light grazing, respectively. Grazing was lighter than planned more often than it was heavier on the moderate and hcavy pastures and heavier than planned more often than lighter on the light pastures. Some departures from planned levels of grazing appear to be inevitable, given the year-to-year variability of herbage production and the difficulty of estimating residual herbage. The large overlap in GPI among treatments indicated that the treatment called "heavy" actually covered almost the entire range of GPI during the study (Fig. 1).

Given the wide range of GPI on the heavily-grazed pastures, calculating mean gains for each grazing intensity would not be meaningful. A more useful approach would be to calculate the relationship between grazing pressure index (GPI) and heifer gain. Average daily gain (ADG) decreased linearly as GPI increased with no indication of a critical GPI below which ADG remained constant (Fig. 1). The predictive equation was $\mathrm{ADG}_{(\mathrm{kg})}=0.787-0.00364 \mathrm{GPI}$, in heifer-days $\mathrm{Mg}^{-1}$ peak standing crop: $\mathrm{r}^{2}=0.45$. Two points (GPI $=13.4, \mathrm{ADG}=1.20$ and GPI $=48.8, \mathrm{ADG}=0.16$ ) appear to be anomalous. Unfortunately, the original biomass and heifer weight data on which these and other points from the early years of this study are based are no longer available to check calculations of ADG and GPI. Grazing pressure index accounts for only about half of the variation in gain. Other factors include breed and initial weight and condition of the cattle; inter- and intra-year variation in nutrient concentrations in the forage; and weather- and health-related stresses on the cattle. 


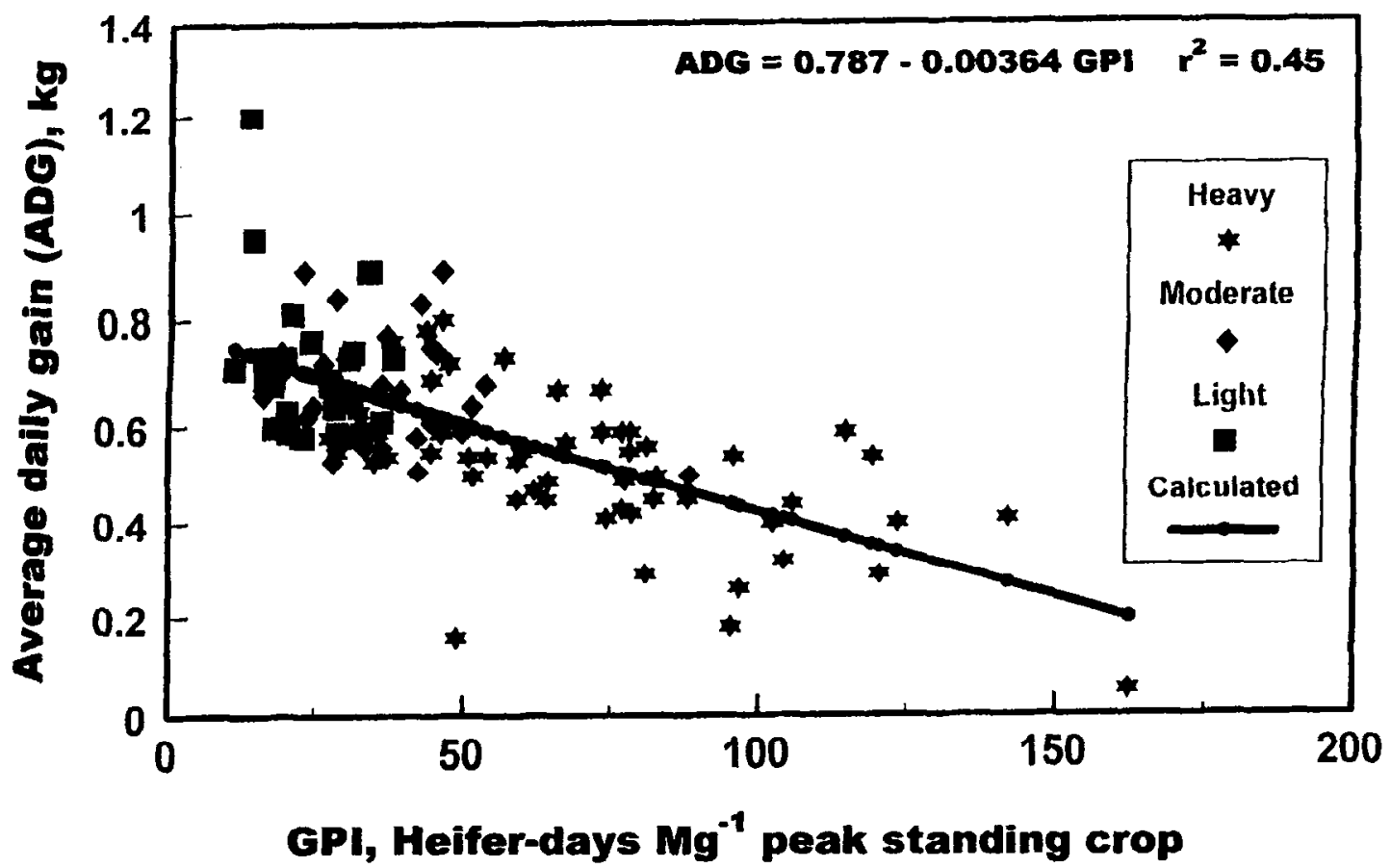

Fig. 1. Average daily gain (ADG) of beifers vs. grazing pressure index (GPI, heifer-days Mg-1 peak standing crop) on rangeland pastures grazed at 3 intensities, 1939-1994.

On shortgrass range under continuous and 3-pasture rest-rotation grazing at the Southeastern Colorado Research Center from 1969 through 1980 , average daily gain in $\mathrm{kg}=1.21-0.0106 \mathrm{GPI}$, when GPI = grazing pressure index in steer-days per $\mathrm{Mg}$ of forage production; $\mathrm{r}^{2}=0.81$ (Cook and Rittenhouse 1988). Maximum gain of steers was higher than that of heifers at CPER, and gain decreased more rapidly as GPI increased.

\section{Discussion and Conclusions}

When evaluating effects of grazing on plant communities, it is necessary to ask "In comparison to what?" The use of ungrazed exclosures or relict areas as standards of comparison is suspect because such areas have rarely existed in nature. Milchunas et al. (1992) concluded that "ungrazed communities (at CPER) were more similar to disturbed communities than were grazed communities."

Larson (1940) considered the shortgrass plains to be a true climax, not a grazing disclimax, because bison and other large herbivores were an integral part of the ecosystem as it developed. With this evolutionary history, it is not surprising that total biomass of relatively palatable graminoids and forbs was as high under moderate grazing as in ungrazed exclosures, and biomass of less palatable shrubs and pricklypear was much lower. Furthermore, total plant basal cover increased under moderate and heavy grazing, although litter cover decreased. Milchunas et al. (1992) also reported that heavy grazing by cattle at the CPER increased total basal cover and basal cover of the dominant species and decreased abundance of native and exotic opportunistic species. They concluded "The unusual and apparently favorable response of shortgrass plant communities has been explained by invoking evolutionary history."
The idea persists that profitable stocking rates may be too high to sustain range condition and production. This perception has been called the "blame-the-profit-motive fallacy" (Workman 1986). Torell et al. (1989) defined "dynamic optimal stocking rates" as those which were based on impacts to future herbage production as well as immediate profitability, and "myopic optimal stocking rates" as rates which were based only on immediate profitability. They tested the difference between dynamic and myopic optimal stocking rates, using the data of Sims et al. (1976). The area where the data were collected was not quite true shortgrass steppe; while dominated by blue grama, it also included significant amounts of prairie sandreed (Calamovilfa longifolia [Hook.] Scribn.), sand bluestem (Andropogon hallii Hack.), needle-and-thread, western wheatgrass, and sand sage (Artemisia filifolia Torr.). Torell et al. (1989) concluded that the profit motive of the cattle producer will not result in economicallybased or myopic stocking rates high enough to significantly deteriorate this range type. They calculated that, in the long run, moderate stocking would result in forage production about $15 \%$ less than that under light grazing, but this level of forage production would be sustainable and would produce higher profits than light grazing. The model of Milchunas et al. (1994) predicted a similar level of forage production, predicting that forage production in a wet and an average year, after $60 \%$ removal for 50 years, would be $5 \%$ and $18 \%$, respectively, less than production under light grazing.

The relation of gain to grazing pressure index can be used to calculate profitability under a range of stocking rates, forage production levels, and cattle prices (Hart 1978). The STEERISK spreadsheet (Hart 1991), developed on rangelands just outside the shortgrass steppe, is equally applicable to shortgrass rangelands. We calculated optimum stocking rates with STEERISK, using an initial heifer weight of $300 \mathrm{~kg}$, purchase price of $\$ 1.87 \mathrm{~kg}^{-1}(\$ 0.85$ 
$\left.\mathrm{lb}^{-1}\right)$, selling price of $\$ 1.65 \mathrm{~kg}^{-1}\left(\$ 0.75 \mathrm{lb}^{-1}\right)$, interest rate of $12 \%$, and grazing season of 170 days. Peak standing crop (excluding pricklypear) was set at 439,640 , and $841 \mathrm{~kg} \mathrm{ha}^{-1}$, equal to mean PSC over the 55 years of the study and mean \pm 1 standard deviation. Optimum stocking rates were 19.2, 28.0, and 36.8 heiferdays $\mathrm{ha}^{-1}$, respectively, and estimated returns to land, labor and management were $\$ 5.05, \$ 7.37$, and $\$ 9.68$. Mean stocking rates over 55 years at the low, moderate and high grazing intensities were $16.7,23.0$, and 36.5 heifer-days ha ${ }^{-1}$, respectively. Although the average optimum stocking rate, as calculated by STEERISK, will shift somewhat with changes in cattle prices, generally it will be only slightly higher than the moderate stocking rate in this study. Plant community responses indicated that this rate should be both profitable and sustainable, with no reduction in total grazable forage production and no marked increase in shrubs and pricklypear, but with some shift towards greater dominance of warm-season grasses.

Just as wild herbivore grazing was sustainable for millennia (Larson 1940), profitable livestock grazing on the shortgrass steppe has been sustainable for over a century (Hart 1998). Climatic, atmospheric and economic changes may require compensating changes in grazing management to insure continued profitability and sustainability.

\section{Literature Cited}

Bement, R. E. 1969. A stocking-rate guide for beef production on bluegrama range. J. Range Manage. 22:83-86.

Bement, R. E. 1974. Strategies used in managing blue-grama range on the Central Great Plains, p. 160-166. In: K. W. Kreitlow and R. H. Hart (eds.) Plant morphogenesis as the basis for scientific management of range resources. USDA Misc. Pub. 1271. Washington, DC.

Cook, C. W., and L. R. Rittenhouse. 1988. Grazing and seeding research at the Southeastern Colorado Experiment Station, Springfield, Colorado. Colorado State Univ. Agr. Exp. Sta. Tech. Bull. LTB88-8. Fort Collins, Colo.

Goulden, C. H. 1952. Methods of statistical analysis, 2nd ed. John Wiley \& Sons, New York, N.Y.

Guerrero, J. N., B. E. Conrad, E. C. Holt, and H. Wu. 1984. Prediction of animal performance on bermudagrass pasture from available forage. Agron. J. 76:577-580.

Hart, R. H. 1972. Forage yield, stocking rate, and beef gains on pasture. Herb. Abstr. 42:345-353.

Hart, R. H. 1978. Stocking rate theory and its application to grazing on rangelands, p. 550-553. In: D. N. Hyder (ed.) Proc. 1st Int. Rangeland Congress. Soc. Range Manage, Denver, Colo.

Hart, R. H. 1991. Managing range cattle for risk-the STEERISK spreadsheet. J. Range Manage. 44:227-231.

Hart, R. H. 1998. Land use history of the shortgrass steppe. In: W. K. Lauenroth and I. Burke (eds.) Ecology of the Shortgrass Steppe: Perspectives from Long-term Research. Oxford Press, New York, N. Y. (in press).

Hart, R. H., and J. A. Hart. 1997. Rangelands of the Great Plains before European settlement. Rangelands 19:4-11.

Hart, R. H., and B. E. Norton. 1988. Grazing management and vegetation response, p. 493-525. In: P. T. Tueller (ed.) Vegetation science-applications for rangeland analysis and management. Kluwer Acad. Publ., Dordrecht, Netherlands.

Hart, R. H., E. F. Balla, and J. W. Waggoner Jr. 1983. Gains of steers and calves grazing crested wheatgrass. J. Range Manage. 36:483-484.

Hart, R. H., W. H. Marchant, J. L. Butler, R. E. Hellwig, W. C. McCormick, G. W. Burton, and B. L. Southwell. 1976. Steer gains under six systems of Coastal bermudagrass utilization. J. Range Manage. 29:372-375.

Hart, R. H., M. J. Samuel, P. S. Test, and M. A. Smith. 1988a. Cattle, vegetation, and economic responses to grazing systems and grazing pressure. J. Range Manage. 41:282-286.
Hart, R. H., J. W. Waggoner Jr., T. G. Dunn, C. C. Kaltenbach, and L. D. Adams. 1988b. Optimal stocking rate for cow-calf enterprises on native range and complementary improved pastures. J. Range Manage. 41:435-441.

Hyder, D. N., R. E. Bement, E. E. Remmenga, and D. F. Hervey. 1975. Ecological responses of native plants and guidelines for management of shortgrass range. USDA Tech. Bull. 1503. Washington, D. C.

Hyder, D. N., R. E. Bement, E. E. Remmenga, and C. Terwilliger Jr. 1965. Frequency sampling of blue grama range. J. Range Manage. 18:90-93.

Klipple, G. E., and D. F. Costello. 1960. Vegetation and cattle responses to different intensities of grazing on short-grass ranges on the Central Great Plains. USDA Tech. Bull. 1216. Washington, D. C.

I arson, F. 1940. The role of bison in maintaining the short grass plains. Ecol. 21:113-121.

Lauenroth, W. K. and D. G. Milchunas. 1992. Short-grass steppe, p 183-226. In: R. T. Coupland (ed.) Natural Grasslands: Introduction and Western Hemisphere. Elsevier, Amsterdam.

Launchbaugh, J. L. 1957. The effect of stocking rate on cattle gains and on native shortgrass vegetation in west-central Kansas. Kansas Agr. Exp. Sta. Bull. 394. Manhattan, Kans.

Launchbaugh, J. L. 1967. Vegetation relationships associated with intensity of summer grazing on a clay upland range site in the Kansas 20- to 24inch precipitation zone. Kansas Agr. Exp. Sta. Tech. Bull. 154. Manhattan, Kans.

McCartor, M. M., and F. M. Rouquette, Jr. 1977. Grazing pressures and animal performance from pearl millet. Agron. J. 69:983-987.

Milchunas, D. G., J. R. Forwood and W. K. Lauenroth. 1994. Productivity of long-term grazing treatments in response to seasonal precipitation. J. Range Manage. 47:133-139.

Milchunas, D. G., W. K. Lauenroth and P. L. Chapman. 1992. Plant competition, abiotic, and long- and short-term effects of large herbivores on demography of opportunistic species in a semiarid grassland. Oecologia 92:520-531.

Milchunas, D. G., W. K. Lauenroth, P. L. Chapman, and M. K. Kazempour. 1989. Effects of grazing, topography, and precipitation on the structure of a semiarid grassland. Vegetatio 80:11-23.

Milchunas, D. G., W. K. Lauenroth, P. L. Chapman, and M. K. Kazempour. 1990. Community structure relaptionships along a perturbation gradient encompassing different types of disturbances in the shortgrass steppe. J. Veg. Sci. 1:375-384.

Mitchell, G. C. 1971. Spatial distribution and successional state of grassland vegetation related to grazing intensity treatments. US/IBP Grassl. Biome Tech. Rep. 101. Fort Collins, Colo.

Moir, W. H., and M. J. Trlica. 1976. Plant communities and vegetation pattem as affected by various treatments in shortgrass prairies of northeastern Colorado. SW Natur. 21:359-371.

Mueller-Dombois, D., and H. Ellenberg. 1974. Aims and methods of vegetation ecology. John Wiley \& Sons, New York, N. Y.

Scarnecchia, D. L. 1985. The relationship of stocking intensity and stocking pressure to other stocking variables. J. Range Manage. 38:558-559.

Shoop, M. S., and E. H. Mcllvain. 1963. The micro-unit forage inventory method. J. Range Manage. 16:172-179.

Sims, P. L., B. E. Dahl, and A. H. Denham. 1976. Vegetation and livestock response at three grazing intensities on sandhill rangeland in eastern Colorado. Colorado State Univ. Exp. Sta. Tech. Bull. 130. Fort Collins, Colo.

Sims, P. L., D. W. Uresk, D. L. Bartos, and W. K. Lauenroth. 1971. Herbage dynamics on the Pawnee site: Aboveground and belowground herbage dynamics on the four grazing intensity treatments, and preliminary sampling on the ecosystem stress site. US IBP Grassland Biome Tech. Rep. 99. Fort Collins, Colo

Tonell, L. A., W. W. Riggs and R. H. Hart. 1989. Economic principles and intertemporal considerations for efficient grazing use of rangeland, $p$. 46-80. In: F. Wagstaff and D.Reesman (eds.) Multiple users-multiple products. Soc. Range Munage., Denver, Colo.

Vavra, M., R. W. Rice, R. M. Hansen, and P. L. Sims. 1977. Food habits of cattle on shortgrass range in northeastern Colorado. J. Range Manage. 30:262-263.

Workman, J. P. 1986. Range economics. MacMillan, New York, N. Y. 